\title{
Organogenesis of Dendrobium Orchid Using Traditional Media and Organic Extracts
}

\author{
S. AKTER $^{1 *}$, K. M. NASIRUDDIN ${ }^{2}$ AND A.B.M. KHALDUN ${ }^{3}$ \\ ${ }^{1 \& 2}$ Department of Biotechnology, Bangladesh Agricultural University, Mymensingh, Bangladesh \\ ${ }^{3}$ Department of Plant Breeding, Bangladesh Agricultural Research Institute, Gazipur, Bangladesh
}

\begin{abstract}
The study was undertaken with a view to investigate the effects of different basal media and organic extracts on organogenesis of Dendrobium orchid. Protocorm like bodies (PLBS) were cultured in Knudson $C(K C)$, Vacin and Went (VW), half strength Murashige and Skoog (1/2MS) and New Phalaenopsis (NP) media supplemented with Sabri banana pulp (Sb), Charcoal (C) and Coconut water (CW) organic extracts. $K C, V W, 1 / 2 M S$ and NP media significantly influenced the plantlet regeneration of Dendrobium orchid. Among the media, 1/2MS showed better performance on fresh weight, number PLBs, shoots and leaves per plantlet, The longest shoots were found in KC medium and maximum length of leaves was found in both $K C$ and $1 / 2 M S$ media. In case of different organic extracts Sb showed significantly better performance on fresh weights of PLBs, number of shoot and leaves per explant, length of shoots and leaves.
\end{abstract}

Key words: Organogenesis, Dendrobium, media, organic extracts.

\section{INTRODUCTION}

Dendrobium orchids are the most popular cut flowers in the orchid floral trade, especially in the Southeast Asian countries. Its mainly requires dry warm and humid environment with abundant sun light for optimum growth and flowering, that are prevailing in Bangladesh. Rapid growth, easiness in plantlet regeneration, year round production under controlled flowering, beauty of flower and long lasting of flower stalk are the advantages in orchids especially in Dendrobium. The stem of Dendrobium species are used in making baskets in the Philippines, Indonesia and New Guinea and pseudobulbs of $D$. takai are used as oral contraceptives (Bose and Bhaltacharjee, 1999).

Orchids grow in a wide range of media and the main components of most plant tissue culture media are mineral salts and sugar as carbon source and water. In addition, orchids depend on the media for mechanical support. The media and its formulation are extremely important to maximize orchid's vigor. A number of media are used for plant tissue culture and these are extensively reviewed by George et al. (1987). Some tissues respond much better on solid media, while others on liquid media A large number of complex additives like coconut water, banana pulp, peptone, tomato juice, slap honey and beef extract can be very effective in providing undefined mixture of organic nutrients and growth factors. For in vitro growth of PLBs and seedlings some complex organic additives reported satisfactory while some have unsatisfactory and even inhibitory (Arditti, 1967).

* Corresponding author: C/O- Krisibid Mafizul Haque, Senior Asstt. Registrar, National University, Gazipur.E-mail: mhaquenu@yahoo.com

(C) 2006 School of Agriculture and Rural Development, Bangladesh Open University, All rights reserved. 


\section{S. Akter et al.}

Many studies on micropropagation methods have already been conducted to establish a suitable method. Rotor (1949) for the first time tried to propagate Phalaenopsis clonaly using flower stalk buds. Other research reports on the micropropagation of orchids through tissue culture of leaf (Tanaka 1987); root tips (Tanka et al. 1976) internodal section of flower stalk (Homma and Asahira 1985; Lin 1986) and lateral buds from young flower stalks (Ichihashi 1992) are available but none of these methods proved to be effective commercially in producing lots of plantlets in a short period because of low rate of PLB (Protocorm Like Body) formation, low viability of PLB, consuming long time for obtaining PLB and different responses among PLB and hybrids (Tokuhara and Mii 1993).

Considering the above idea in mind the present study was undertaken to investigate the effects of different media and organic additives on plantlet regeneration from PLB and its subsequent growth in Dendrobium.

\section{MATERIALS AND METHODS}

The experiment was carried out at the USDA Biotechnology Laboratory, Bangladesh Agricultural University, Mymensingh during the period from February to April, 2006 to investigate the effect of different media and organic extracts on organogenesis of Dendrobium orchid. In vitro multiple PLBs were cultured on the Vacin and Went (Vacin and Went 1949), Knudson C (Knudson 1946), half strength Murashige and Skoog (Murashige and Skoog 1962) and New Phalaenopsis (New Phalaenopsis) media supplemented with charcoal (0. 1\% w/v), Sabri banana pulp (10\% w/v) and coconut water $(10 \% \mathrm{v} / \mathrm{v})$. After preparing the media $\mathrm{P}^{\mathrm{H}}$ was adjusted to 5.8 with digital $\mathrm{P}^{\mathrm{H}}$ meter adding $0.1 \mathrm{~N} \mathrm{NaOH}$ or $0.1 \mathrm{~N} \mathrm{HCl}$. Agar powder $(10 \mathrm{~g} / \mathrm{l})$ was added to solidify the media. The culture vials containing the media were autoclaved with $1.16 \mathrm{~kg} / \mathrm{cm}^{2}$ of pressure at $121^{\circ} \mathrm{c}$ for 20 minutes. Thirty six glass vials were labeled and set up under twelve treatments with three replications. Four in vitro multiple PLBs were placed in each vial. All the culture vials were placed in a growth room and allowed to grow at $25 \pm 1^{\circ} \mathrm{C}$ under 16 hour photoperiod illuminated with fluorescent tube of 2000-3000 lux. On the basis of media and organic extract the experiment considered two factors (i) Media (ii) organic extract. The experiment was laid out in Completely Randomized Design (CRD). The data were collected and recorded at 20 days interval up to 60 days on fresh weight of PLBs explant $^{-1}$, number of PLBs explant ${ }^{-1}$, number of shoots explant ${ }^{-1}$, length of shoots, number of leaves plantlet $^{-1}$ and length of leaves. The treatment means were compared based on Lest Significant Difference (LSD), Zaman et al. (1983).

\section{RESULTS AND DISCUSSION}

The results obtained from the present study are presented and discussed with figures and tables under the following headings.

\section{Fresh weight of PLBs}

Different media showed a significant effect on fresh weight of PLBs at 20 DAl but not at 40 and 60 DAl. At $20 \mathrm{DAl}$, the fresh weight of PLBs in $1 / 2 \mathrm{MS}$ media was significantly higher $(0.33 \mathrm{~g})$ than those of other media. No significant difference of the fresh weight of PLBs was found between KC and VW media. At $40 \mathrm{DAl}$, the highest $(0.39 \mathrm{~g})$ and lowest $(0.33 \mathrm{~g})$ fresh weight of PLBs was obtained from NP and KC media, respectively. At $60 \mathrm{DAl}$, the highest $(0.57 \mathrm{~g})$ and lowest $(0.49 \mathrm{~g})$ of fresh weight of PLBs was from $1 / 2 \mathrm{MS}$ and VW media, respectively (Fig. 1). It appears from the present study that $1 / 2 \mathrm{MS}$ medium showed superiority in fresh weight of PLBs over others at 20 and 60 DAls. It might be due to higher nitrate and relatively lower sulphate and phosphate content of $1 / 2 \mathrm{MS}$ medium than other media. Haque (1996) found similar effect in garlic (Allium Sativum). Khatun (2005) found $0.24 \mathrm{~g}$ and $0.19 \mathrm{~g}$ fresh weight of PLBs from KC and VW media, respectively at 60 DAI in Dendrobium orchid.

Different organic extracts showed highly significant effect on the fresh weight of PLBs at all DAls. At $20 \mathrm{DAl}$, the highest $(0.31 \mathrm{~g})$ fresh weight and lowest $(0.16 \mathrm{~g})$ fresh weight of PLBs were obtained from Sabri banana pulpe and Charcoal. At 40 DAI, the fresh weight of PLBs on Sabri 
banana pulpe was significantly higher $(0.47 \mathrm{~g})$ than those on other organic extracts. No significant difference of fresh weight of PLBS was observed between Charcal and Coconut water. Similar trends were found at $60 \mathrm{DAl}$ (Table.1).It appears from the present study that Sabri banana had superiority in fresh weight of PLBs over other extracts at all DAls. Higher concentrations of sucrose and other nutrients in Sabri banana pulp had a promotive effect on fresh weight of PLBs, Singh (1995).

\section{Number of PLBs}

Different media showed a significant effect on number of PLBs at 20, 40 and 60 DAl. At 20 and 40 $\mathrm{DAl}$, the number of PLBs in $1 / 2 \mathrm{MS}$ was significantly higher than those on other media. At $40 \mathrm{DAl}$, no significant variation of the number of PLBs was found between VW and NP media. At 60 DAl, the highest (33.57/explant) and lowest (17.92/explant) number of PLBs were obtained from $1 / 2 \mathrm{MS}$ and VW media, respectively. No significant variation of the number of PLBs per explants was found between KC and NP media at 60 DAI (Fig. 2). The highest number of PLBs on $1 / 2 \mathrm{MS}$ medium in this study might be due higher nitrate and relatively lower sulphate and phosphate content of $1 / 2 \mathrm{MS}$ medium than other media. Haque (1996) found similar effect in garlic (Allium Sativum). Lakshmana et al. (1995) observed average of 13.5 PLBs in VW medium. Rahman et al. (2004) reported that NP medium enhanced the subsequent growth of mini plantlet of Doritacenopsis orchid. Shyamal and Pinik (2004) showed the best regenerated shoots of Vanda ters when grown on VW medium containing $10 \%$ coconut water.

The number of PLBs was significantly influenced by different organic extracts at all DAls. At 20 DAI, the number of PLBs in Sabri banan pulp was significantly higher (11.85 /explants) than those in other organic extracts. No significant variation of the number of PLBs was found between Charcoal and Coconut water. At 40 DAl, the numbers of PLBs in Coconut water were lowest (12.68 lexplant). No significant variation of the number of PLBs was found between the organic extracts Sabri banana pulp and Charcoa. At 60 DAI, Coconut water showed the highest (26.26/explant) number of PLBs (Table.1). Chen and Chen (1998) reported that the best plantlets were grown on banana extract. It appears from the present study that Coconut water showed superiority over others.

Table 1: Effects of different organic extracts on plantlet regeneration from PLB and its subsequent growth in Dendrobium

\begin{tabular}{|c|c|c|c|c|c|c|c|c|c|c|c|c|c|c|c|c|c|c|}
\hline \multirow[t]{2}{*}{ Treatment } & \multicolumn{3}{|c|}{$\begin{array}{l}\text { Fresh weight } \\
\text { of PLBs (g) } \\
\text { at different } \\
\text { days after } \\
\text { inoculation } \\
\end{array}$} & \multicolumn{3}{|c|}{$\begin{array}{c}\text { Number of } \\
\text { PLBs at } \\
\text { different days } \\
\text { after } \\
\text { inoculation } \\
\end{array}$} & \multicolumn{3}{|c|}{$\begin{array}{l}\text { Number of } \\
\text { shoots at } \\
\text { different } \\
\text { days after } \\
\text { inoculation }\end{array}$} & \multicolumn{3}{|c|}{$\begin{array}{c}\text { Length of } \\
\text { shoots }(\mathrm{cm}) \\
\text { at different } \\
\text { days after } \\
\text { inoculation } \\
\end{array}$} & \multicolumn{3}{|c|}{$\begin{array}{l}\text { Number of } \\
\text { leaves at } \\
\text { different } \\
\text { days after } \\
\text { inoculation } \\
\end{array}$} & \multicolumn{3}{|c|}{$\begin{array}{l}\text { Length of } \\
\text { leaves }(\mathrm{cm}) \\
\text { at different } \\
\text { days after } \\
\text { inoculation }\end{array}$} \\
\hline & 20 & 40 & 60 & 20 & 40 & 60 & 20 & 40 & 60 & 20 & 40 & 60 & 20 & 40 & 60 & 20 & 40 & 60 \\
\hline Sh & $0.31^{\mathrm{a}}$ & $0.47^{\mathrm{a}}$ & $0.71^{\mathrm{a}}$ & $11.85^{\mathrm{a}}$ & $17.13^{\mathrm{a}}$ & $24.28 a^{b}$ & $8.27^{\mathrm{a}}$ & $15.01^{\mathrm{ab}}$ & $25.32^{\mathrm{a}}$ & $0.61^{\mathrm{a}}$ & $0.93^{a}$ & $1.30^{\mathrm{a}}$ & $1.04^{\mathrm{a}}$ & $1.81^{\mathrm{a}}$ & $2.26^{a}$ & 0.36 & $0.38^{\mathrm{a}}$ & $0.57^{\mathrm{a}}$ \\
\hline C & $0.16^{c}$ & $0.28^{b}$ & $0.41^{b}$ & $7.95^{b}$ & $16.04^{b}$ & $23.74^{b}$ & $2.13^{b}$ & $5.74^{b}$ & $14.04^{b}$ & $0.36^{b}$ & $0.69^{b}$ & $0.99^{b}$ & $0.46^{b}$ & $1.21^{b}$ & $1.97^{b}$ & 0.21 & $0.25^{b}$ & $0.46^{\mathrm{a}}$ \\
\hline $\mathrm{Cw}$ & $0.24^{b}$ & $0.34^{b}$ & $0.47^{b}$ & $8.43^{b}$ & $12.68^{b}$ & $26.26^{\mathrm{a}}$ & $2.15^{b}$ & $6.85^{b}$ & $13.01^{b}$ & $0.28^{b}$ & $0.66^{b}$ & $0.97^{b}$ & $0.42^{b}$ & $1.18^{b}$ & $1.91^{b}$ & 0.12 & $0.20^{b}$ & $0.33^{b}$ \\
\hline LUD & 051 & 0.096 & 0.088 & 1.361 & 1.884 & 2.064 & 0.813 & 1.600 & 1.915 & 0.099 & & & & 300 & 0.1 & NS & 0.6 & 0.116 \\
\hline
\end{tabular}

In a column, figures followed by same letter(s) don't differ significantly at $\mathrm{P}<0.05$ as per DMRT

Note: $\mathrm{Sb}=$ Sabri banana pulp, $\mathrm{C}=$ Charcoal, $\mathrm{Cw}=$ Coconut water, $\mathrm{LSD}=$ Least significant difference

NS = Non significant

\section{Number of shoots}

Different media showed a significant effect on number of shoots at 20, 40 and 60 DAl. At 20 DAl, the highest number of shoots ( 7.27 /explant) was found in $1 / 2 \mathrm{MS}$ media and lowest (1.94 /explant) 


\section{S. Akter et al.}

was in NP media. No significant difference of the number of shoots was observed between $\mathrm{KC}$ and $\mathrm{VW}$ media. At $40 \mathrm{DAl}$, the number of shoots in $1 / 2 \mathrm{MS}$ medium was significantly higher than those of other media. No significant difference of the number of shoots was observed between KC and NP media (Fig. 3).From the present experiment, it appears that the number of shoots gradually increased with time and $1 / 2 \mathrm{MS}$ medium had superiority over other media. This result was partially support result observed by Talukder et al. (2003), where they obtained the highest number of proliferated shoots (11.13/explant) on MS medium containing BAP.

The number of shoot of in Sabri banana pulp was significantly higher than those of other organic extracts at all DAls. No significant variation of the number of shoots per explants was found between the organic extracts Charcoal and Coconut water (Table. 1). Sabri banana pulp appeared the best at all DAls due to higher percentage (27\%) of sucrose concentrations, Singh (1995).

\section{Length of shoots}

Length of shoots on $1 / 2 \mathrm{MS}$ medium was significantly higher $(0.64 \mathrm{~cm})$ at 20 DAl than those on other media. However, at 40 and $60 \mathrm{DAl}$, length of single shoots on $\mathrm{KC}$ medium was significantly higher than those on other media. At $40 \mathrm{DAl}$, no significant difference of the length of single shoots was observed among KC, VW and $1 / 2 \mathrm{MS}$ media. At $60 \mathrm{DAI}$, the higher $(1.29 \mathrm{~cm})$ and lower $(0.84 \mathrm{~cm})$ length of single shoots was found from KC and NP media, respectively (Fig. 4).Martini (2001) observed large number of plantlets on MS medium in Gongora.

The length of shoot on Sabri banana pulp was significantly higher than those on others at all DAls. No significant variation of the length of single shoot was found between Charcoal and Coconut water. (Table.1). Higher percentage (27\%) of sucrose in of Sabri banana pulp might be responsible for the promotive effect on the length of shoot at all DAls.

\section{Number of leaves}

The number of leaves on $1 / 2 \mathrm{MS}$ medium was significantly higher (2.83 / plantlet) than those on other media at all DAls (Fig. 5). The number of leaves on NP medium was significantly lower (1.47/ plantlet) than those on other media. No significant difference of the number of leaves was found between the KC and VW media. The number of leaves gradually increased with time and $1 / 2 \mathrm{MS}$ medium had superiority to others media at all DAls. This result is in agreed with that of Davidson (1994) who reported that the number of leaves of Dendrobium species was higher in MS medium than in KC medium. Hye (2003) also observed highest number of leaves (5.28/ plantlet) in hybrid orchid on MS medium at 90 DAI.

The highest number (2.26 / plantlet) of leaves was obtained from Sabri banana pulp (Table. 1) at all DAIS. It might be due to the higher concentrations of sucrose and other nutrient contents in sabri banana pulp, Singh (1995).

\section{Length of leaves}

At $40 \mathrm{DAl}$, the length of leaves of NP medium was significantly lower $(0.22 \mathrm{~cm})$ than those on other media. No significant difference of the length of leaves was observed among the KC, VW and half strength MS media (Fig. 6).At $60 \mathrm{DAl}$, the highest length $(0.48 \mathrm{~cm})$ of leaves was found in both $\mathrm{KC}$ and half strength MS media.

Different organic additives showed a significant variation in leaf length at 40 and 60 DAIs. The length of leaves on Sabri banana pulp was significantly higher than those on others (Table. 1). Higher percentage (27\%) of sucrose in Sabri banana pulp extract might have a promotive effect on the length of leaves.

It revealed from the present study that $1 / 2 \mathrm{MS}$ medium supplemented with Sabri banana pulp is the most suitable for organogenesis of Dendrobium orchid. 


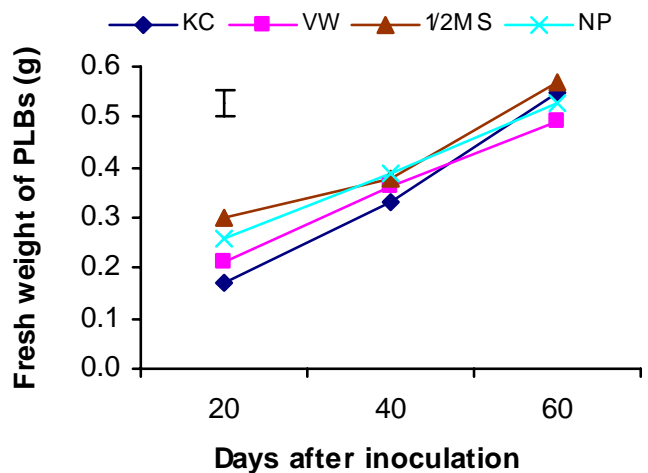

Fig. 1. Effect of different media on fresh weight of PLBs at different DAIs. Vertical bar represent LSD at $5 \%$ level of probability

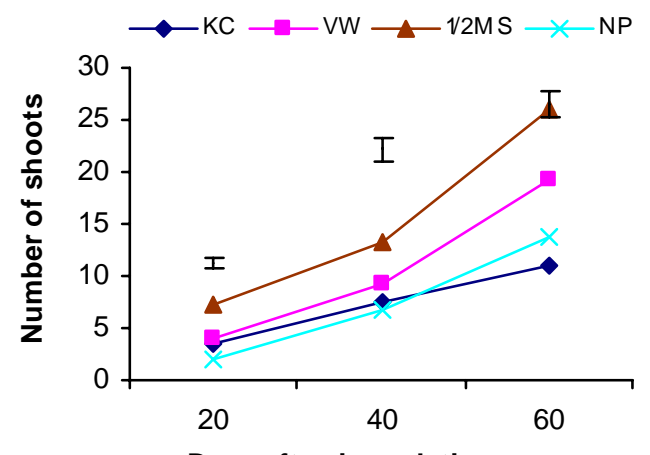

Days after inoculation

Fig. 3. Effect of different media on number of shoots at different DAls. Vertical bars represent LSD at $5 \%$ level of probability

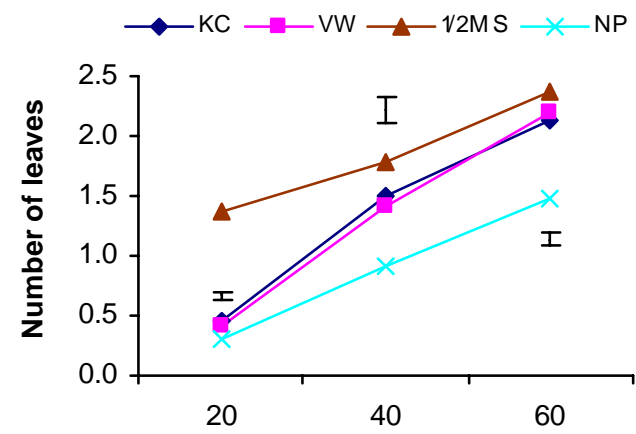

Days after inoculation

Fig. 5. Effect of different media on number of leaves at different DAI. Vertical bars represent LSD at $5 \%$ level of probability

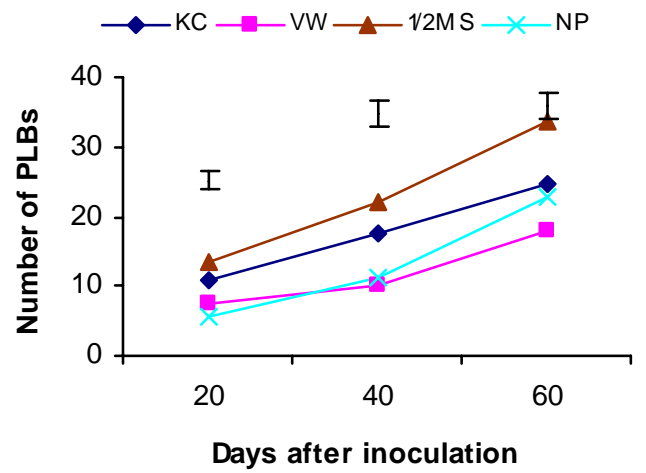

Fig. 2. Effect of different media on number of PLBs at different DAIs. Vertical bars represent LSD at $5 \%$ level of probability

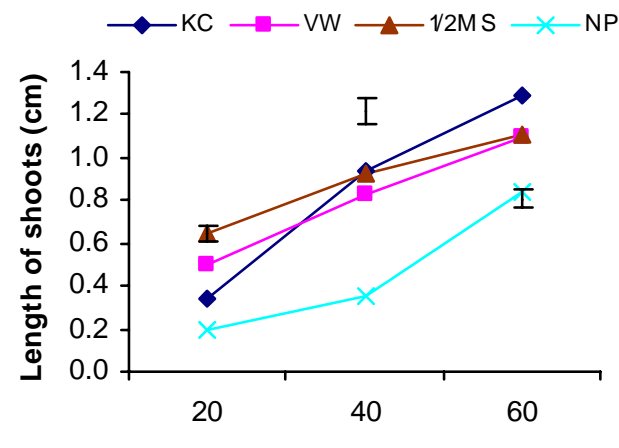

Days after inoculation

Fig. 4. Effect of different media on length of shoots at different DAIs. Vertical bars represent LSD at $5 \%$ level of probability

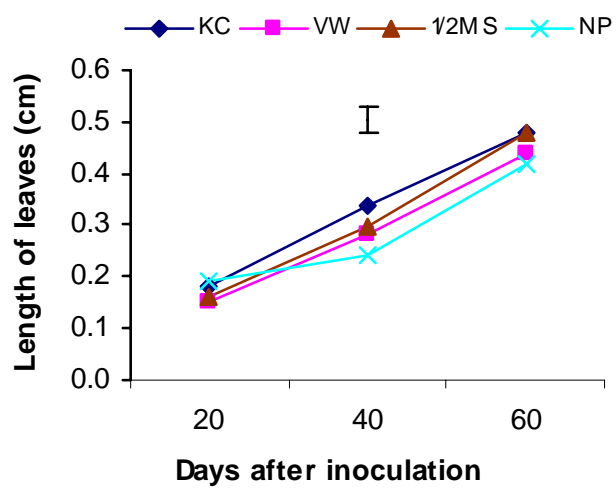

Fig. 6. Effect of different media on length of leaves at different DAls. Vertical bars represent LSD at $5 \%$ level of probability 


\section{S. Akter et al.}

\section{LITERATURE CITED}

Arditti, J. 1967. "Orchid Biology: Reviews and Perspective", IL. Cornel University Press. Ithaea, New York. 325 pp.

Bose, T. K., Bhattacharjee, S. K., Das, P. and Basak, U. C. 1999. "Importance, distribution, classification, propagation and cultivation of orchids. Orchids of India", Naya Prakash, Calcuta, India. 1-77 pp.

Chen, F. C. and Chen, T. C. 1998. Effect of salt strength and organic additives on the in vitro growth of protocorm like bodies and plantlets of Oncidium Gower Ramsey. Journal of Chines Horticulture Society. 44(4), 403-412.

Davidson, B., 1994. Dendrobium breeding trends. American Orchid Society Bulettin.63, 617-618.

George, E. F., Puttock, D. J. M. and George, H. J. 1987. "Plant Culture Media. Vol. I. Formulations and Uses". Exegetics Ltd. Basingstoke UK.

Haque, M. S. 1996. Studies on the micropropagation of garlic (Allium sativum). [MSThesis]. Laboratory of Plant Genetics and Breeding, School of Agricultural Science. Nagoya University. Japan. 86 pp

Homma, Y. and Ashira, T. 1985. New means of phalaenopsis propagation with internodal sections of flower stalk. Journal of Japan. Horticulture Science. 53, 379-387.

Hye, M. A. 2003. Organogenesis of hybrid orchid with different media supplementation. [MS Thesis] Department of Horiculture, Bangladesh Agricultural University, Mymensingh

Ichihashi, S. 1992. Micropropagation of Phalaenopsis through the culture of lateral buds from young flower stalks. Lindleyana, 7(4), 208-215.

Khatun, H. 2005. Effect of Plant Growth Regulators on Growth and Development of Hybrid Orchid. [MS Thesis], Department of Biotechnology, Bangladesh Agricultural University, Mymensingh.

Knudson, C. 1946. A new nutrient solution for germination of orchid seed. American Orchid Society Bulletin. 15, 214-217.

Lakshmanan, P. C., Loh, C. S. and Goh, C. J. 1995. An in Vitro method for rapid regeneration of a monpodial orchid hybrid Aranda beborah using thin section culture. Plant Cell Report. 14(8), 510-514.

Lin, E. E. 1986. In vitro culture of flower stalk internodes of Phalaenopsis and Doritaenopsis Lindlayana. 1, 158163.

Martini, P. C., Willadino, L., Alves, G. D. and Donato, V. M. T. S. 2001. Propagation of orchid Gongora quinquenrvis by in vitro germination. Pesquisa Agropecuaria Brasileira, 36(10),1319-1324.

Murashige, I. and Skoog, F. 1962. A revised medium for rapid growth and bioassys with tobacco tissue culture. Plant Physiology.15, 473-497.

Rahman, A. R. M., Islam, M. O., Azad-ud-doula, A. K. M. and Ichihashi.S. 2004. Effect of complex organic Extracts on Plantet growth in the Doritaenopsis Orchid. Journal Agricultural Research. 38(1), 55-59.

Rotor, G. 1949. A method of vegetative propagation of Phalaenopsis species and hybrids. American Orchid Society Bulletin. 18, 738-739.

Shyamal, K. and Sinha, P. 2004 Regeneration of an Indigenous Orchid, Vanda teres (Roxb.) Lindl. Through in vitro Culture. Journal of Plant Tissue Culture 14(1), 55-62.

Singh, S. P. (1995). Commercial Fruits. Kalyani Publishers, Ludhiana, New Delhi. pp. 165-171.

Talukder, S. K., Nasiruddin, K. M., Yesmin, S., Hassan, L. and Begum, R. 2003. Shoot Proliferation of Dendrobium orchid with BAP and NAA. Journal of Biological Sciences. 3(11), 1058-1062.

Tanaka, M. 1987. Studies on the clonal propagation Phalaenopsis through in vitro culture. Member, Facultyl of Agriculture, Nagoya University. Japan. 49, 1-85.

Tanaka, M., Senda, Y. and Hasegawa, A. 1976. Plantlet fromation by root tip culture in Phalaenopsis. American Orchid Society Bulletin. 56, 1024-1032.

Tokuhara, K. and Mii, M. 1993. Micropropagation of Phalaenopsis by culturing shoot tips of flower stalk buds. Plant Cell Reports. 13(10), 7-11.

Vacin. E. and F. Went. 1949. Some pH changes in nutrient solution. Botanic Gardens Conservation News. 110, 605-613.

Zaman, S. M. H., Rahim, K. and Howlader, M.1983. Simple Lessions from Biometry. BARI, Joydebpur, Gazipur. pp. 77-90. 